\title{
EVALUATING THE PARSĘTA BASIN COMMUNES' TOURIST SPACE USING THE SELECTED QUANTIFICATION METHODS
}

\author{
Dominik Jan Domin, Grzegorz KwiatKowski, Justyna ChodKowsKa-Miszczuk
}

Nicolaus Copernicus University, Institute of Geography, Department of Urban and Recreation Studies, Torun, Poland

Manuscript received: December 20, 2009

Revised version: August 1, 2010

Domin D.J., Kwiatкowski G. \& Chоркоwska-Miszczuk J., 2010. Evaluating the Parsęta basin communes' tourist space using the selected quantification methods. Quaestiones Geographicae 29(3), Poznań 2010, pp. 21-26, 1 Fig., 3 Tabs. ISBN 978-83-62662-04-3. ISSN 0137-477X. DOI: 10.2478/v10117-010-0019-0.

АВSTRACT: Identifying differences in the factors determining tourism development in an area is crucial to utilising its natural, economic and socio-cultural resources that enable sustainable development of the tourist function. This article sets out to present and estimate factors underlying tourism development in the context of various quantification methods and the comparisons of their results. The phenomenon selected for the research is evaluated using tools such as a synthetic measure Gołembski (2002) (based on weights assigned to particular features) and two synthetic measures Perkal (z-scores) (1953) and Zioło (1985).

KeYWORDs: capacity for tourism, tourist function, Parsęta Basin, Western Pomerania, Poland

Dominik Jan Domin, Grzegorz Kwiatkowski, Justyna Chodkowska-Miszczuk, Nicolaus Copernicus University, Institute of Geography, Department of Urban and Recreation Studies, Gagarina 9, 87-100 Toruń, Poland, e-mail: djdomin@umk.pl, gkwiat@doktorant.umk.pl,jchodkow@doktorant.umk.pl

\section{Introduction}

Factors determining tourism development were evaluated for 20 communes lying in the basin of the Parsęta River (that flows directly to the Baltic Sea). The analysis covered the rural communes as well as the rural parts of the urban and rural communes. Considered in terms of the administrative division in the country, the investigated area represents the eastern part of the Western Pomeranian voivodeship.

This article evaluates the tourism development factors using 27 diagnostic features that are discussed more in detail in the article: Evaluation of conditions concerning the development of tourism. Investigation into the basin of the Parsęta river (Domin et al. 2009).

\section{Research methods}

As already mentioned, the multivariate analysis methods are described in the article, which necessitate selecting variables and giving them appropriate weights.

The presented multivariate analysis was performed using a six-step procedure.

1. Selection of a set of the diagnostic features see Table 1. 
Table 1. The diagnostic features and their weights

\begin{tabular}{|c|c|c|}
\hline $\begin{array}{c}\text { Set } \\
\text { (weight) }\end{array}$ & $\begin{array}{c}\text { Subset } \\
\text { (local/global weight) }\end{array}$ & $\begin{array}{c}\text { Variable } \\
\text { (local/global weight) }\end{array}$ \\
\hline \multirow{13}{*}{ 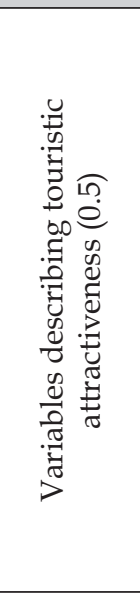 } & \multirow{8}{*}{$\begin{array}{c}\text { Touristic } \\
\text { amenities } \\
(0.55 / 0.275)\end{array}$} & A share of forests in the area of a commune (\%): 0.15/0.04125 \\
\hline & & A share of meadows and pastures in the area of a commune (\%): 0.05/0.01375 \\
\hline & & A number of lakes per $1 \mathrm{~km}^{2}: 0.05 / 0.01375$ \\
\hline & & Lake occurrence (\%): 0.05/0.01375 \\
\hline & & Sea access. zero-one method: $0.30 / 0.08250$ \\
\hline & & A number of religious centres per $1 \mathrm{~km}^{2}: 0.05 / 0.01375$ \\
\hline & & A number of natural monuments per $1 \mathrm{~km}^{2}: 0.05 / 0.01375$ \\
\hline & & A number of architectural monuments per $1 \mathrm{~km}^{2}: 0.05 / 0.01375$ \\
\hline & \multirow{3}{*}{$\begin{array}{c}\text { Transport } \\
\text { availability } \\
(0.15 / 0.075)\end{array}$} & A length of roads per $1 \mathrm{~km}^{2}: 0.70 / 0.05250$ \\
\hline & & A frequence of train stops: $0.25 / 0.01875$ \\
\hline & & A number of working railway stations per 1.000 inhabitants: $0.05 / 0.00375$ \\
\hline & \multirow{2}{*}{$\begin{array}{c}\text { Touristic } \\
\text { infrastructure } \\
(0.30 / 0.150) \\
\end{array}$} & Baretje/Defert's rate: $0.80 / 0.12000$ \\
\hline & & A number of hotels and restaurants per 1.000 inhabitants: $0.20 / 0.03000$ \\
\hline \multirow{14}{*}{ 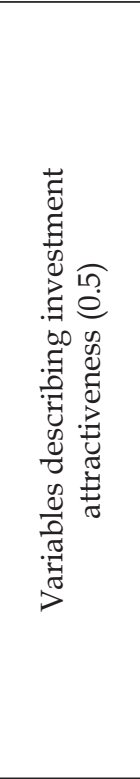 } & \multirow{4}{*}{$\begin{array}{c}\text { Service } \\
\text { infrastructure } \\
(0.30 / 0.150)\end{array}$} & A number of shops per 1,000 inhabitants: $0.35 / 0.05250$ \\
\hline & & A number of petrol stations per $1 \mathrm{~km}^{2}: 0.35 / 0.05250$ \\
\hline & & $\begin{array}{l}\text { A number of pharmacies and ambulatory care facilities per } 1.000 \\
\text { inhabitants: } 0.20 / 0.03000\end{array}$ \\
\hline & & A number of post offices per 1.000 inhabitants: $0.10 / 0.01500$ \\
\hline & \multirow{4}{*}{$\begin{array}{c}\text { Technical } \\
\text { infrastructure } \\
(0.25 / 0.125)\end{array}$} & A percentage of inhabitants served by sewage treatment plants $(\%): 0.35 / 0.04375$ \\
\hline & & A percentage of inhabitants using waterworks (\%): 0.35/0.04375 \\
\hline & & Sewage network in $\mathrm{km}$ per $1 \mathrm{~km}^{2}: 0.15 / 0.01875$ \\
\hline & & Waterworks in $\mathrm{km}$ per $1 \mathrm{~km}^{2}: 0.15 / 0.01875$ \\
\hline & \multirow{4}{*}{$\begin{array}{l}\text { Socio-demographic } \\
\text { conditioning } \\
(0.30 / 0.125)\end{array}$} & $\begin{array}{l}\text { A number of non-productive age inhabitants per } 100 \text { persons in productive age: } \\
0.20 / 0.02500\end{array}$ \\
\hline & & Population density per $1 \mathrm{~km}^{2}: 0.30 / 0.03750$ \\
\hline & & $\begin{array}{l}\text { A share of working inhabitants among the productive age inhabitants (\%): } \\
0.30 / 0.03750)\end{array}$ \\
\hline & & $\begin{array}{l}\text { A share of the unemployed with relation to the working age inhabitants (\%): } \\
0.20 / 0.02500\end{array}$ \\
\hline & \multirow{2}{*}{$\begin{array}{c}\text { Economic } \\
\text { conditioning } \\
(0.15 / 0.075) \\
\end{array}$} & Revenue per 1,000 inhabitants: 0.80/0.06000 \\
\hline & & A share of expenditure on culture and national heritage (\%): 0.20/0.01500 \\
\hline
\end{tabular}

Source: developed by the authors based on Domin et al. (2009)

2. Focusing the direction of preferences, i.e. transforming all features being originally destimulants into stimulants. To this end, a method given by the formula below was applied:

$$
y_{i j}=\max \left(x_{i}\right)-x_{j}
$$

where:

$\mathrm{i}$ - commune's number $(\mathrm{i}=1, \ldots, \mathrm{m})$,

$\mathrm{j}$ - variable's number $(\mathrm{j}=1, \ldots, \mathrm{n})$,

$x_{i j}$ - the value of the $j$-th diagnostic feature in the $i$-ith commune,

$y_{i j}$ - the value of the $j$-th diagnostic feature being a stimulant in the $i$-th commune,

$\max \left(x_{j}\right)$ - the maximal value of the initial $j$-th diagnostic feature in the communes;
3. Normalization of the features. The selected research methods are at variance already at the stage of feature normalization.

- in the Perkal's (z-scores) method (1953), the data are normalized by the formula:

$$
x_{i}^{\prime}=\frac{x_{i}-\bar{x}}{\sigma_{x}}
$$

- the Gołembski's method (2002) uses the normalization where the particular features are compared with the maximum value in the set:

$$
x_{i}^{\prime}=\frac{x_{i}}{\max (x)}
$$


- the Zioło's method (1985) uses the normalization where the particular features are compared with the totalled values of variables in the set:

$$
x_{i}^{\prime}=\frac{x_{i}}{\sum_{i=1}^{m} x_{i}}
$$

where:

$x_{i}^{\prime}$ - the post-normalisation value of a feature; $\max (x)$ - the maximal value of a feature;

$\bar{x}$ - the average value of a feature;

$\sigma_{x}$ - the standard deviation of value;

$i$ - commune's number in the set $(i=1, \ldots, m)$

$m$ - the number of the communes.

4. More differences can be found when a measure's total value is calculated using the general formula:

$$
w=\frac{\sum_{j=1}^{n} w_{j} x_{j}}{\sum_{j=1}^{n} w_{j}}
$$

where:

$j$ - feature's number $(j=1, \ldots, n)$,

$n$ - the number of the features

$w_{j}$ - the weight of the $j$ feature.

The Gołembski's method (2002) principally assumes that the particular diagnostic features and their sub-sets differently contribute to the final evaluation outcome. Hence, they receive different weights (see Table 1) that the researcher selects using their subjective judgment. Because the weights add up to 1 , a simplified Gołembski's formula (2002) allowing the calculation of a synthetic measure takes the form:

$$
w_{G}=\sum_{j=1}^{n} w_{j} x_{j}
$$

On the other hand, the Perkal (1953) and Zioło (1985) evaluation methods recognise the features as having the same influence, so equal weights are given to them. Then, a simplified Perkal's formula for calculating the measure's values is given by:

$$
w_{P}=\frac{\sum_{j=1}^{n} x_{j}}{n}
$$

The Zioło's method employs the same equation to estimate the values of a synthetic measure.
It must be mentioned, though, that the Zioło's method (1985) additionally provides an insight into data structure because the percentage shares of the particular normalized measures in their total value are calculated (Runge 2007). This aspect is only being signalled, as it is outside the scope of this article. Besides, there are a relatively large number of publications available in market, which deal with quantitative methods applied to geographical research (Kostrubiec 1977; Norcliffe 1986; Berry \& Linoff 1997; Walesiak 2009).

5 . The obtained results vis-à-vis the spatial dimension (Fig. 1).

6. A comparison of the method-specific results. Calculations of Spearman's rank correlation.

\section{Results and discussion}

As shown by the calculations made using the three quantification methods, the particular communes in the Parsęta Basin show considerably different values and rankings (see Table 2).

Different methods make rankings vary, with the differences ranging from 6 to 12 rankings in the extreme cases, as exemplified by the Siemyśl, Bobolice, Połczyn Zdrój and Rąbino communes (Table 2). At the same time, some rankings are a very similar, e.g. the Ustronie Morskie, Kołobrzeg, Karlino, Szczecinek and Czaplinek communes.

An analysis of rank correlation between communes' rankings obtained using different analytical methods (see Table 3) reveals strong relationships between the compared methods. In the examined situation, the choice of a variable normalization method had an insignificant effect on the final result of the analysis (Table 3). Besides, even though different weights were assigned to the analyzed features in the Gołembski's method (the weights were different even 32 times), its results were similar to those produced by the methods where feature weights were not differentiated.

It is worth noting that a considerable disproportion can be seen between the first and the second communes (Ustronie Morskie and Kołobrzeg, respectively) and the other communes (see Table 2 ), regardless of the method applied. This suggests that the first two communes have basically 
Table 2. Comparison of the values and rankings obtained for the communes

\begin{tabular}{|c|c|c|c|c|c|c|c|}
\hline \multirow{3}{*}{ Communes } & \multicolumn{6}{|c|}{ Methods } & \multirow{3}{*}{ An average rank } \\
\hline & \multicolumn{2}{|c|}{ G. Gołembski } & \multicolumn{2}{|c|}{ J. Perkal } & \multicolumn{2}{|c|}{ Z. Zioło } & \\
\hline & value & $\operatorname{rank}^{(1)}$ & value & rank & value & rank & \\
\hline Ustronie $\mathrm{M}$. & 0.67 & 1 & 1.14 & 1 & 17.9 & 1 & 1 \\
\hline Kołobrzeg & 0.50 & 2 & 0.47 & 2 & 11.2 & 2 & 2 \\
\hline Dygowo & 0.39 & 6 & 0.22 & 3 & 7.3 & 3 & 3 \\
\hline Czaplinek & 0.44 & 3 & 0.13 & 5 & 7.1 & 5 & 4 \\
\hline Borne S. & 0.40 & 5 & 0.13 & 6 & 7.1 & 4 & 5 \\
\hline Szczecinek & 0.44 & 4 & 0.09 & 7 & 6.6 & 6 & 6 \\
\hline Gościno & 0.39 & 7 & 0.18 & 4 & 6.1 & 9 & 7 \\
\hline Biały Bór & 0.36 & 8 & -0.01 & 9 & 6.1 & 8 & 8 \\
\hline Biesiekierz & 0.35 & 11 & 0.01 & 8 & 6.5 & 7 & 9 \\
\hline Tychowo & 0.36 & 9 & -0.16 & 15 & 5.3 & 12 & 10 \\
\hline Grzmiąca & 0.34 & 14 & -0.1 & 12 & 5.6 & 11 & 11 \\
\hline Siemyśl & 0.27 & 20 & -0.05 & 10 & 6.1 & 10 & 12 \\
\hline Karlino & 0.34 & 13 & -0.1 & 13 & 5.2 & 14 & 13 \\
\hline Rąbino & 0.30 & 18 & -0.09 & 11 & 5.1 & 15 & 14 \\
\hline Rymań & 0.32 & 17 & -0.17 & 16 & 5.3 & 13 & 15 \\
\hline Sławoborze & 0.32 & 16 & -0.11 & 14 & 5.1 & 17 & 16 \\
\hline Połczyn Z. & 0.35 & 12 & -0.21 & 18 & 5.1 & 19 & 17 \\
\hline Bobolice & 0.35 & 10 & -0.24 & 20 & 4.4 & 20 & 18 \\
\hline Barwice & 0.34 & 15 & -0.2 & 17 & 5.1 & 18 & 19 \\
\hline Białogard & 0.28 & 19 & -0.24 & 19 & 5.1 & 16 & 20 \\
\hline
\end{tabular}

${ }^{(1)}$ value 1 represents the best commune in the group.

different conditions, i.e. definitely better, for developing tourism than all the other region along the Parsęta river.

The cartograms show strong variations in the communes assigned to particular groups representing a specific category: very high, high, low and very low. At the same time, the stripes corresponding to the region's physico-geographical stripes remain visible (see Kondracki 2000), regardless of which research method was used. This proves that the calculations were correct and that the general trends were captured; the appearing

Table 3. The analysis of rank correlation between communes' rankings obtained using different analytical methods

\begin{tabular}{|c|c|c|}
\hline Methods* & $\begin{array}{c}\text { Calculations } \\
\text { of Spear- } \\
\text { man's rank } \\
\text { correlation }\end{array}$ & $\begin{array}{c}\text { Statistically } \\
\text { significant } \mathbf{a}\end{array}$ \\
\hline G vs P & 0.71 & 0.0005 \\
\hline G vs Z & 0.74 & 0.0005 \\
\hline P vs Z & 0.96 & 0.0005 \\
\hline G vs population mean & 0.84 & 0.0005 \\
\hline P vs population mean & 0.96 & 0.0005 \\
\hline Z vs population mean & 0.96 & 0.0005 \\
\hline
\end{tabular}

${ }^{*}$ G - Gołembski; P - Perkal; Z - Zioło. differences (first in the values obtained and then in the rankings) are due to the variations in the mathematical calculations.

Introducing the averaged rankings seems a rational approach, as this allows formulating a more objective opinion on the linear distribution of the tourism development factors in the Parsęta Basin using the three methods. This approach produces a new ranking representing an average of the discussed research methods (see Table 2).

That somewhat different results were obtained can be attributed to the subjective selection of the features for analysis and of their weights (in the G. Gołembski's method). Particular authors use different features that are relevant to the character of the areas they examine (Milewski 2005; Pietrzyk-Sokulska 2006). Adding or removing even a seemingly unimportant single feature may affect communes' rankings (Pérez et al. 2006); the comparative analyses show, though, that different authors arrive at moderately similar results (Pawlicz 2008). 
G.

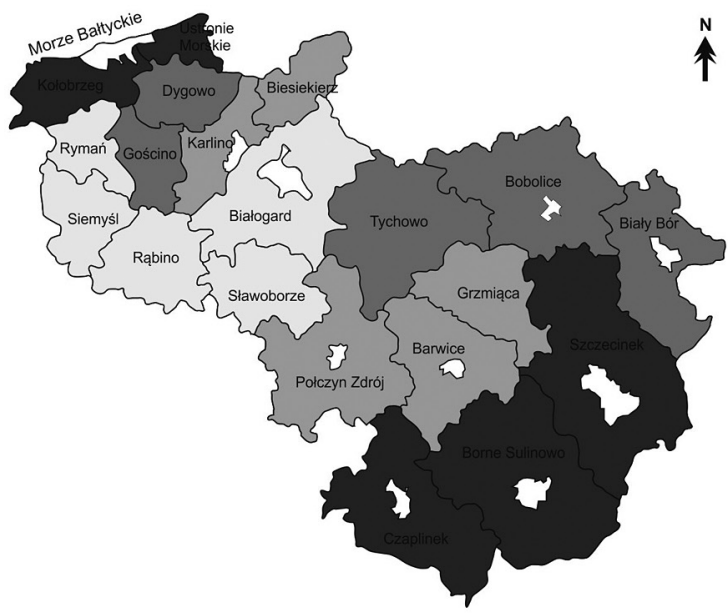

P.
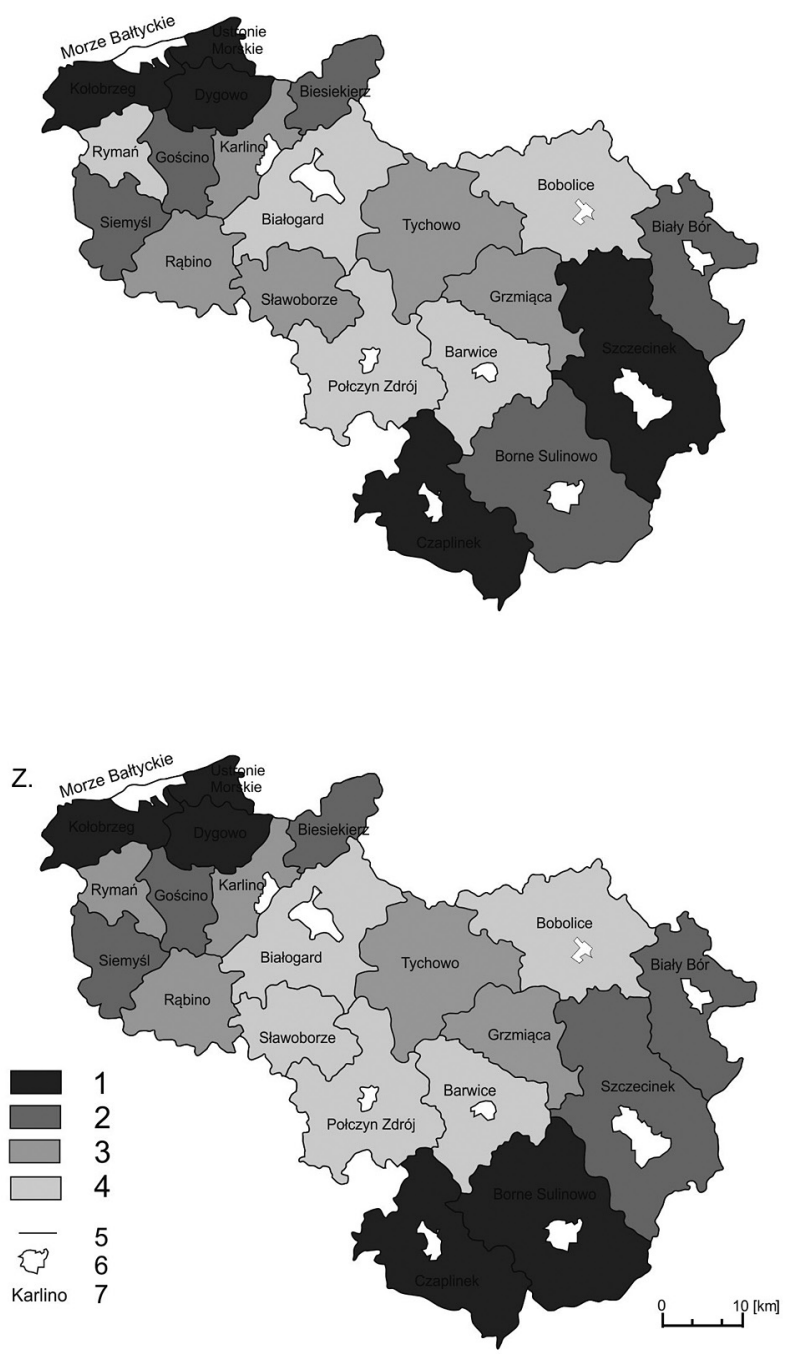

Fig. 1. Evaluation of the tourism development factors in the Parsęta Basin communes with respect to the three quantification methods.

Note: G. - Gołembski`s method, Z. - Zioło`s method, P. - Perkal`s method, 1 - very high, 2 - high, 3 - low, 4 - very low, 5 - commune borderline, 6 - town area, 7 - name of a commune

\section{Conclusions}

The research results lead to the following final conclusions:

1. The tourism development factors in the Parsęta Basin are distributed in relation to the physico-geographical stripes in the region.

2. The northernmost communes in the region that touch the sea (Ustronie Morskie and Kołobrzeg) have much better conditions for developing tourism.

3. The natural factors (few lakes or none at all, lower forest cover indicator) in the central communes in the region make them less suitable for developing tourism, likewise their relatively low level of socio-economic development compared with the areas in northern and southern parts of the Basin, etc.

4. As shown by the research results, trying to estimate the tourism development factors using the outcomes of only one quantification method may overly simplify the reality and even distort it. The methods are generally not found to be different, yet considerably different estimates can be produced for the particular evaluated units. It is therefore recommended that all analyses (in both tourism geography and other fields) use at least several quantification methods to substantiate a more objective final evaluation

\section{Acknowledgements}

"Grant for PhD students 2008/2009-ZPORR" - 2.6 ZPORR, No Z/2.04/II/2.6/20/09 project funded $75 \%$ from the European Social Fund, the European Union and $25 \%$ from the National Budget. Expenses incurred in accordance with the provisions of the grant agreement under the project "Grant for PhD Students 2008/2009-ZPORR" No agreement SPS.IV-3040-UE/209/2009 concluded on 08.05.2009 with the Kujawsko-Pomorskie Voivodeship.

\section{References}

Berry M.J.A. \& Linoff G., 1997. Data mining techniques: for marketing, sales and customer support. John Willey \& Sons, Chichester. 
DOMin D.J., KWIATKOWSKI G. \& SZYMAŃSKA D., 2009. Evaluation of conditions concerning the development of tourism. Investigation into the basin of the Parsęta river. Bulletin of Geography. Socio-economic Series 11: 75-87. DOI: 10.2478/ v10089-008-0021-7.

GoŁemвsкi G., 2002. Wyodrębnianie regionów turystycznych. In: G.Gołembski (ed.), Kompendium wiedzy o turystyce. Wydawnictwo Naukowe PWN, Warszawa-Poznań: 325-333.

KONDRACKI J., 2000. Geografia regionalna Polski. Wydawnictwo Naukowe PWN, Warszawa.

Kostrubiec B., 1977. Metody badania koncentracji przestrzennej. In: Z.Chojnicki (ed.), Metody ilościowe i modele w geografii. Państwowe Wydawnictwo Naukowe, Warszawa: 63-76.

MiLEwski D., 2005. Regionalne uwarunkowania rozwoju turystyki na przykładzie województwa zachodniopomorskiego. Uniwersytet Szczeciński, Szczecin.

Norcliffe G.B., 1986. Statystyka dla geografów. Państwowe Wydawnictwo Naukowe, Warszawa.
Pawlicz A., 2008. Promocja produktu turystycznego. Turystyka miejska. Centrum Doradztwa i Informacji Difin, Warszawa.

Pérez J., Jimeno J. \& Mокотоff E., 2006. Another potential shortcoming of AHP. TOP 14(1): 99-111.

Perkal J., 1953. O wskaźnikach antropogenicznych. Przeglad Antropologiczny 19: 209-221.

PietrZYK-SOKUlSKa E., 2006. Typologia gmin. In: J.Warszyńska (ed.), Turystyka zrównoważona na obszarze Beskidów Zachodnich. Studium uwarunkowań $i$ barier rozwoju. Instytut Gospodarki Surowcami Mineralnymi i Energią PAN, Kraków: 149-175.

RUNGE J., 2006. Metody badań w geografii społeczno-ekonomicznej - elementy metodologii, wybrane narzędzia badawcze. Wydawnictwo Uniwersytetu Śląskiego, Katowice.

WALESIAK M., 2009. Podstawowe zagadnienia statystycznej analizy wielowymiarowej. In: M.Walesiak, E.Gatnar (eds.), Statystyczna analiza danych z wykorzystaniem programu R. Wydawnictwo Naukowe PWN, Warszawa: 62-80.

ZıоŁo Z., 1985. Zastosowanie miernika syntetycznego w badaniach układów przestrzennych w geografii przemystu. Seminarium Sekcji Geografii Przemysłu PTG. WSP Kraków: 1-11. 